\title{
Combining abilities and inbreeding depression in commercial maize hybrids
}

\section{Capacidades combinatórias e depressão por endogamia de híbridos comerciais de milho}

\author{
Henrique José Camargo Senhorinho ${ }^{1 *}$; Ronald José Barth Pinto ${ }^{2}$; \\ Carlos Alberto Scapim²; Klayton Flávio Milani³; Thiago Hideyo Nihei ${ }^{1}$
}

\begin{abstract}
The objective of this study was to evaluate the combining ability and inbreeding depression of commercial maize hybrids for agricultural traits. Twenty-two commercial maize hybrids, $96 \mathrm{~F}_{1}$ crosses from a partial diallel scheme, $22 \mathrm{~S}_{1}$ populations and 4 controls were evaluated in a $12 \times 12$ simples square lattice experimental setup, totaling 144 treatments, in the municipality of Sabáudia (PR), Brazil, for harvests from 2011/2012 and 2012/2013. Three traits were evaluated: grain yield, plant height and ear height. The Griffing method (1956) was applied for the evaluation of the general combining ability (GCA) and specific combining ability (SCA). The 30B39, 30K64 and 30B30 hybrids showed increased yield, 30F53 and P1630 showed reduced plant height and AG9040 and AG7010 showed reduced ear height. These hybrids can be recommended for the extraction of inbred lines and formation of composites followed by intrapopulation selection. The combinations 30B39 x AG8088, 30B39 x AG9045 and P1630 x AG8021 showed desirable SCA effects for grain yield, plant height and ear height and are recommended for use in reciprocal recurrent selection programs. High magnitudes of inbreeding depression were verified for yield and lower values for inbreeding depression for plant and ear heights. Thus, strategies are recommended for interpopulation breeding accompanied by inbred lines extraction. Key words: Zea mays L., diallel analysis, heterosis, grain yield
\end{abstract}

\section{Resumo}

O objetivo do trabalho foi avaliar a capacidade combinatória e a depressão endogâmica de híbridos de milho, para caracteres agronômicos. Foram avaliados 22 híbridos comerciais, 96 combinações $F_{1}$ oriundas de um dialelo parcial, 22 populações $\mathrm{S}_{1}$ e 4 testemunhas, avaliados em dois experimentos delineados em látice quadrado $12 \times 12$ totalizando 144 treatments conduzidos em Sabáudia (PR), nas safras 2011/2012 e 2012/2013. Foram avaliados três caracteres: produtividade, altura de plantas e altura de espigas. O método de Griffing (1956) foi aplicado para a avaliação da capacidade geral (CGC) e específica (CEC) de combinação. Destacaram-se os híbridos 30B39, 30K64 e 30B30 para aumentar a produtividade, 30F53 e P1630 para reduzir a altura de plantas e AG9040 e AG7010 para a redução de altura de espigas. Tais híbridos podem ser recomendados para extração de linhagens e formação de compostos seguida de seleção intrapopulacional. As combinações 30B39 x AG8088, 30B39 x AG9045 e P1630 x AG8021 apresentaram efeitos de CEC desejáveis para rendimento de grãos, altura de plantas e altura de espigas, sendo recomendadas para uso em programas de melhoramento interpopulacional.

\footnotetext{
${ }^{1}$ Discentes de Doutorado em Genética e Melhoramento Vegetal, Universidade Estadual de Maringá, UEM, Maringá, PR, Brasil. E-mail: hsenhorinho@hotmail.com; thiagonihei@hotmail.com

2 Profs. Drs., UEM, Maringá, PR, Brasil. E-mail: rjbp@uem.br; cascapim@uem.br

3 Pesquisador, Syngenta do Brasil, Lucas do Rio Verde, MT, Brasil. E-mail:kf_milani@hotmail.com

* Author for correspondence
} 
Foram verificadas altas magnitudes de depressão endogâmica para a produtividade e menores valores de depressão para a altura de plantas e de espigas. Assim, são recomendadas estratégias de melhoramento interpopulacional acompanhadas de extração de linhagens.

Palavras-chave: Zea mays L., análise dialélica, heterose, rendimento de grãos

\section{Introduction}

The choice of germplasm to be used in a breeding program is essential in defining the potential for the development of new cultivars, considering that gains through selection are limited by what the germplasm can offer (HALLAUER et al., 2010). Exemplifying this importance, in 1980, 19\% of all parental materials of hybrids in the United States were inbred lines extracted from a single population, the Iowa Stiff Stalk Synthetic (BSSS), one of the most frequently used germplasms in the world (LAMKEY et al., 1991). In a more recent plan, Mikel (2011) studied the genetic compositions of more than 300 inbreds with registered pedigrees in the United States between 2004 and 2008 and from various private breeding programs from the US and concluded that just two germoplasms, the BSSS and Iodent, together contributed with more than two-thirds of the genes in these inbred lines.

Maize, as a cultivated and selected specie in the most diverse environments in the world, shows large variability in many agronomic traits, and for this reason, numerous accessions are available to breeders, each with its respective genetic constitution (HALLAUER et al., 2010).

The use of commercial hybrids is one of the most interesting options for breeding programs, especially in relation to the acquisition of superior inbred lines. Commercial hybrids, especially simple-cross hybrids, shows high productivities and satisfactory adaptation, given the large proportion of favorable loci already fixed due to strong selective pressure during their development in the breeding process (LIMA et al., 2000; RAPOSO; RAMALHO, 2004; AMORIM; SOUZA, 2005).

Various criteria can guide the definition of populations to be used as basic germplasms in breeding programs. One of the most important results comes from the evaluation of the combining abilities of the materials involved. This evaluation can be performed using diallel crossings, a widely used methodology to obtain information about the behaviors of parents and segregating populations per se and in hybrid combinations. Diallels also allows to ascertain the roles of different mechanisms of genetic action involved in the inheritance of analyzed quantitative traits (CRUZ; VENCOVSKY, 1989). Among the most used methods for diallel analysis are the proposals from Griffing (1956), Gardner and Eberhart (1966) and Hayman (1954) (CRUZ et al., 2007).

The concept of combining abilities, which is based on the relative performances of the crossed materials, was postulated by Sprague and Tatum (1942) and is expressed as the general combining ability (GCA) or specific combining ability (SCA). The GCA is defined as the average performance of a line in hybrid combinations and is estimated by the difference between the average of its hybrids and the general average for all crossings. Because the GCA is due to the merit of the gametes from each parent, this measure depends on additive genetic action. In turn, the SCA from one crossing is defined as the difference between the value of a specific hybrid combination and the expected performance from this same combination considering only the GCA of the lines involved. Thus, because the SCA depends on genetic complementation, the SCA for each crossing results from non-additive genetic effects (SPRAGUE; TATUM, 1942; MIRANDA FILHO; GORGULHO, 2001; CRUZ et al., 2007).

In evaluating the potential of inbred lines extraction from a given population, the quantification of inbreeding depression constitutes another key point in the choice of a given population, as 
self- pollinization in maize result in an increase in homozygosity, permitting the exposure of the effects of recessive alleles. Thus, lower magnitudes of inbreeding depression are observed in genotypes with lower genetic loads, indicating greater potential for the extraction of superior inbred lines (FALCONER, 1987).

The objectives of this study were to evaluate the performance of 22 commercial maize hybrids, their performances in crossings, and the inbreeding depression of their self-fertilized progeny; to estimate the general and specific combining abilities; and to identify promising materials for the constitution of a basic germplasm in the maize breeding program of the Universidade Estadual de Maringá.

\section{Materials and Methods}

Twenty-two commercial maize hybrids used as parents were divided into two groups. The first group had 16 parents, all from DuPont Pioneer, while the second group had 6 parents, all from Agroceres/Monsanto. Next, hybrids from these specific groups were intercrossed in a partial diallel scheme, without reciprocals, totaling 96 combinations. The 96 hybrid combinations, 22 parents, $22 \mathrm{~S}_{1}$ progeny obtained from these parents and four controls were evaluated in the harvests of 2011/2012 and 2012/2013, in Sabáudia (PR), Brazil. In both experiments, a $12 \times 12$ simple square lattice design was used, for a total of 144 treatments (Table 1).

Table 1. Origin and description of the commercial hybrids used as parents in the partial diallel.

\begin{tabular}{ccc} 
& & \\
\hline Hybrid & Type & Continue ... \\
\hline 30 F35 & Group I - DuPont Pioneer Hybrids & Orange \\
3021 & SH & Orange \\
30 K64 & TH & Orange \\
$30 F 53$ & SH & Orange \\
P3646 & SH & Yellow/Orange \\
P1630 & SH & Yellow/Orange \\
$30 B 39$ & SH & Orange \\
32 R48 & SH & Orange \\
32 R22 & SH & Yellow \\
P3340 & SH & Yellow/Orange \\
P30K73 & SH & Yellow/Orange \\
P4285 & SH & Orange \\
P30F36 & SH & Orange \\
$30 R 50$ & SH & Orange \\
$30 B 30$ & SH & Orange \\
$30 F 80$ & TH & Orange \\
\hline AG8088 & SH & \\
AG7088 & Group II - Agroceres/Monsanto Hybrids & Orange \\
AG9045 & SH & Orange \\
AG8021 & SH & Yellow/Orange \\
AG9040 & SH & Yellow/Orange \\
& SH & Orange \\
\hline & SH & Yellow \\
\hline
\end{tabular}


Continuation

\begin{tabular}{ccl}
\hline & Commercial Controls -Syngenta Hybrids & \\
\hline Cargo & DH & Orange \\
Status & SH & Orange \\
Celeron & SH & Orange \\
Penta & SH & Orange \\
\hline
\end{tabular}

*SH = Simple Hybrid; DH = Double Hybrid; $\mathbf{T H}=$ Triple Hybrid.

The crossings to obtain the hybrid combinations and the self-pollinization to obtain the $\mathrm{S}_{1}$ generations were performed on the Fazenda Experimental de Iguatemi (FEI) of the Universidade Estadual de Maringá, located in Iguatemi/PR, in the second harvest of 2011 .

The experiments were performed in the municipality of Sabáudia/PR, Brazil, in the Sementes Balu Experimental Unit, at an altitude of $725 \mathrm{~m}$, located at $23^{\circ} 19^{\prime} \mathrm{S}$ and $51^{\circ} 33^{\prime} \mathrm{W}$ latitude and longitude, respectively. In the experiments, each plot had a usable area of $9 \mathrm{~m}^{2}$ and consisted of two 5-m rows spaced $0.90 \mathrm{~m}$ apart and thinned at 30 days to a density of 5 plants. $\mathrm{m}^{-1}$, resulting in a population of approximately 55,500 plants.ha ${ }^{-1}$ at the time of harvest. Both experiments were sown in a conventional planting system, the first in the second half of October for the 2011/2012 harvest and the second in the first half of November for the 2012/2013 harvest. Fertilization consisted of the application of $380 \mathrm{~kg} \mathrm{ha}^{-1}$ of the formulation 4-20-20, at sowing, and $140 \mathrm{~kg} \mathrm{ha}^{-1} \mathrm{~N}$, in the form of urea in the covering at 35 days after seedling emergence. The cultivation practices followed the recommendations from Galvão and Miranda (2008) for maize cultivation.

All of the treatments in both harvests were evaluated with respect to average plant height $(\mathrm{PH})$, average height for insertion of the ears $(\mathrm{EH})$ and grain yield, from the productivity of ears husked per parcel, expressed in hectares and corrected for $13 \%$ humidity. For the adjustment of the stand, the Covariance Analysis was adopted, according to Vencovsky and Cruz (1991), considering an ideal stand of 50 plants per plot.

To obtain the adjusted means for each experiment, the following statistical model was used: $\quad Y_{i j k}=\mu+t_{i}+r_{j}+b_{(j) k}+e_{i j k}, \quad$ in which $\mathrm{Y}_{\mathrm{ijk}}$ is the value for the $\mathrm{i}$-th treatment, in the $\mathrm{k}$-th block, in repetition $\mathrm{j}$; $\mu$ is the overall mean; $t_{i}$ is the fixed effect of treatment $i ; r_{j}$ is the random effect of repetition $j ; b_{(j) k}$ is the random effect of block $k$ within repetition $\mathrm{j}$; and $\mathrm{e}_{\mathrm{ijk}}$ is the experimental error. From the adjusted means, a new sum of squares was calculated for treatments, according to Silva et al. (1999). The procedure used can be described as an analysis of the lattice in completely randomized blocks, using the adjusted means of the treatments from the intrablock analysis with recovery of the interblock information, with the average effective variance from this same analysis as the residual mean square.

Before performing the joint analysis, the homogeneity of the average effective variances was evaluated using the Hartley test (HARTLEY, 1950). In the joint analysis, the effects of both treatments and years were considered to be fixed. The joint analysis for the environments was performed using the adjusted means from the individual intrablock analyses, with recuperation of the interblock information, according to the statistical model $Y_{i k}=\mu+t_{i}+a_{j}+t a_{i j}+\bar{e}_{i-j}$, in which $\mathrm{Y}_{\mathrm{ik}}$ is the adjusted mean value of treatment $i$ in environment $\mathrm{j} ; \mu$ is the overall mean of the experiment; $t_{i}$ is the fixed effect of the $i$-th treatment; $a_{j}$ is the fixed effect of the $\mathrm{j}$-th year; $\mathrm{ta}_{\mathrm{ij}}$ is the effect of the interaction of the $\mathrm{i}$-th treatment with the $\mathrm{j}$-th treatment; and $\bar{e}_{i-j}$ is the average experimental error. For the calculations 
of the sums of squares of the sources of variation and for the decomposition of the effects of the treatments, the equations presented by Regazzi et al. (1999) were used.

The diallel analyses of the crosses were performed using the adjusted means of the hybrid combinations separately for each environment, according to model 4 from Griffing (1956), adapted to a partial diallel involving two groups of parents by Geraldi and Miranda Filho (1988). For the joint diallel study of the tests, involving only crosses, the analysis of variance was performed using the method adapted from Griffing (1956) to evaluate the effects of the interaction between the components of the combining ability and of the environment, according to the statistical model $Y_{i j}=\mu+g_{i}+g_{j}+s_{i j}+a_{k}+g_{i k}+g_{j k}+s a_{1 j k}+\bar{e}_{1 j}$. In this model, $Y_{i j}$ is the experimental mean associated with the $\mathrm{i}$-th parent of group 1 and the $\mathrm{j}$-th parent of group 2 ; $\mu$ is the general mean; $g_{i}$ is the effect of the GCA of the i-th parent of group 1; $g_{j}$ is the effect of the GCA of the $j$-th parent of group $2 ; \mathrm{s}_{\mathrm{ij}}$ is the effect of the SCA between the $\mathrm{i}$-th parent of group 1 and the $j$-th parent of group $2 ; a_{k}$ is the effect of environment $\mathrm{k}$; $\mathrm{ga}_{\mathrm{ik}}$ and $\mathrm{ga}_{\mathrm{jk}}$ are the effects of the interaction between the GCA associated with the $\mathrm{i}$-th and $\mathrm{j}$-th parents from groups 1 and 2 , respectively, with the environments; $\mathrm{sa}_{\mathrm{ijk}}$ the effect of the interaction between the SCA between the i-th and $\mathrm{j}$-th parents and the environments; and $\overline{\mathbf{e}}_{\mathbf{i j}}$ is the average experimental error.

Inbreeding depression was quantified in the first generation of self-pollinization of the parents present in the diallel, according to the equation

$$
\mathrm{D}=\left[\frac{\mathrm{F}_{1}-\mathrm{S}_{1}}{\mathrm{~F}_{1}}\right] \cdot 100,
$$

in which $\mathrm{D}=$ inbreeding depression; $\mathrm{F}_{1}=$ mean for the commercial hybrid and $S_{1}=$ mean for the $S_{1}$ population of the commercial hybrid. The potential of the commercial hybrids as sources of inbred inbred lines was studied according to the method proposed by Gardner (1965) and explained by Vencovsky and Barriga (1992), from the expression
$\overline{\mathbf{L}}_{\mathrm{i}}=\hat{\mathbf{u}}+\widehat{\mathbf{a}}=\mathbf{2} \overline{\mathbf{S}}_{1 \mathrm{i}}-\overline{\mathbf{S}}_{01}$, in which $\overline{\mathbf{L}}_{\mathbf{i}}=$ expected means of the pure inbred lines; $\overline{\mathbf{S}}_{1 \mathrm{i}}=$ phenotypic mean value after one generation of self-fertilization; and $\overline{\mathbf{S}}_{\mathbf{0 i}}=$ original phenotypic mean value of the genotypes.

All of the calculations were performed using the program Genes (CRUZ, 2013).

\section{Results and Discussion}

In the analyses of individual variances, the effects of treatments were significant for all of the evaluated traits. The experimental coefficients of variation (CVs) obtained in the first experiment (2011/2012 harvest) were $11.23 \%, 3.71 \%$ and $5.59 \%$ for yield, plant height and ear height, respectively. In the second experiment (2012/2013 harvest), the respective CVs reached $14.17 \%, 4.46 \%$ and $7.34 \%$, indicating satisfactory experimental precision (SCAPIM et al., 1995; FRITSCHE-NETO et al., 2012). The adoption of lattice was also verified as a satisfactory experimental design because all of the estimators of the design efficiency were greater than $100 \%$.

The relationship between the largest and smallest mean squares of the average effective errors of the individual analyses were less than the 7:1 ratio, making the performance of the joint analysis of the data collected in the two tests possible, according to Gomes (1977). The effects of treatments were significant for all of the characteristics evaluated in the joint analysis (Table 2), indicating differences between the average performances of the genotypes involved in the experiment. This response constitutes a key element for the breeding programs, justifying the unfolding of variance in the groups of interest. The effects of the 'treatments $\mathrm{x}$ years' interaction were also significant, indicating a different performance from the genotypes as a function of environmental variations from one year to the next and reflecting specific adaptations for the tested environments. 
Table 2. Analysis of the joint variance of the 12x12 square lattice and the joint diallel analysis from the 2011/2012 and 2012/2013 harvests for grain yield (GY), plant height (PH) and ear height (EH).

\begin{tabular}{|c|c|c|c|c|}
\hline \multirow[b]{2}{*}{ S.V. } & \multirow[b]{2}{*}{ D.F. } & \multicolumn{3}{|c|}{ Mean Square } \\
\hline & & GY $\left(\mathrm{t} \mathrm{ha}^{-1}\right)$ & $\mathrm{PH}(\mathrm{cm})$ & $\mathrm{EH}(\mathrm{cm})$ \\
\hline Rep/Seasons & 2 & - & - & - \\
\hline BdR/Seasons & 44 & - & - & - \\
\hline Seasons & 1 & 306,3384 & 56827,4127 & 86677,1237 \\
\hline Treatments & 143 & $6,7422 *$ & $761,8389^{*}$ & $483,9355^{*}$ \\
\hline Diallel & 117 & $3,6555^{*}$ & $534,0498 *$ & $421,4083^{*}$ \\
\hline Parents $(P)$ & 21 & $7,4435^{*}$ & $451,1393 *$ & $439,3874 *$ \\
\hline$F_{1}$ & 95 & $2,8566^{*}$ & $544,0880 *$ & $419,2297^{*}$ \\
\hline$P v s F_{1}$ & 1 & $0,0093^{\mathrm{ns}}$ & $1321,5366^{*}$ & $250,8075^{\mathrm{ns}}$ \\
\hline$S_{1}$ & 21 & $3,9521 *$ & $427,1352^{*}$ & $265,6461 *$ \\
\hline Control & 3 & $1,8793^{\mathrm{ns}}$ & $337,9207^{*}$ & $87,0580^{\mathrm{ns}}$ \\
\hline Between Groups & 2 & $223,9004 *$ & $18237,7650^{*}$ & $7029,1369 *$ \\
\hline Treatments x Seasons & 143 & $1,6135 *$ & $438,4238 *$ & $250,6028^{*}$ \\
\hline Diallel vs Seasons & 117 & $1,5822 *$ & $364,2831^{*}$ & $225,5616^{*}$ \\
\hline P vs Seasons & 21 & $2,4703^{*}$ & $875,4510^{*}$ & $460,4358^{*}$ \\
\hline$F_{1}$ vs Seasons & 95 & $1,3200^{*}$ & $253,9928 *$ & $175,9588^{*}$ \\
\hline$\left(P v s F_{l}\right) \times$ Seasons & 1 & $7,8433^{*}$ & $107,3380^{\text {ns }}$ & $5,4735^{\mathrm{ns}}$ \\
\hline$S_{1} x$ Seasons & 21 & $0,8506^{\mathrm{ns}}$ & $250,7702 *$ & $269,9591 *$ \\
\hline Controls vs Seasons & 3 & $3,1884 *$ & $648,2213^{*}$ & $346,1859^{*}$ \\
\hline Between Groups vs Seasons & 2 & $9,0918^{*}$ & $6431,3205^{*}$ & $1368,8923 *$ \\
\hline Efective Mean Error & 242 & $\mathbf{0 , 8 5 5 0}$ & 90,8832 & 68,3982 \\
\hline $\mathrm{F}_{1}$ & 95 & $2,8565^{*}$ & $544,0880^{*}$ & $419,2297 *$ \\
\hline GCA I & 15 & $6,3820^{*}$ & $1166,9025^{*}$ & $855,0281^{\mathrm{ns}}$ \\
\hline GCA II & 5 & $10,1971^{\mathrm{ns}}$ & $2631,4117^{\mathrm{ns}}$ & $2956,4561^{*}$ \\
\hline SCA & 75 & $1,6621^{*}$ & $280,3701^{*}$ & $162,9216^{*}$ \\
\hline Seasons & 1 & $135,0175^{*}$ & $57505,8628^{*}$ & $66613,7847^{*}$ \\
\hline $\mathrm{F}_{1} \cdot \mathrm{x}$ Seasons & 95 & $1,3200 *$ & $253,9929 *$ & $175,9588^{*}$ \\
\hline GCA I x Seasons & 15 & $1,3729^{\mathrm{ns}}$ & $359,7429^{*}$ & $367,4175^{*}$ \\
\hline GCA II x Seasons & 5 & $5,5546^{*}$ & $1061,3673^{*}$ & $585,2290 *$ \\
\hline SCA x Seasons & 75 & $1,0271^{\mathrm{ns}}$ & $179,0719 *$ & $110,3723^{*}$ \\
\hline Residual mean & 242 & $\mathbf{0 , 8 5 5 0}$ & 90,8832 & 68,3982 \\
\hline Mean & & 7,3958 & 238,0973 & 131,9009 \\
\hline
\end{tabular}

*: significant in the $\mathrm{F}$ test at a 5\% probability; ns: not significant in the $\mathrm{F}$ test at a $5 \%$ probability.

The significant effects for the variances resulting from the unfolding of the mean square of the treatments indicate that, for Diallel, Parents and Crossings, at least one of the means differed significantly from the others, with an interaction also occurring with the years in which the three traits were evaluated. Troyer (1996) commented that, due to the narrow genetic basis of this hybrid modality, the effect of the interaction of single-cross hybrids with years is frequently significant. However, the same significant effect can be observed within the hybrid combinations formed from parents that, for the most part, are simple hybrids. In this study, it can thus be inferred that, despite the broader genetic basis of the $\mathrm{F}_{1}$ generations obtained in this diallel, the plasticity of the double-cross hybrids considering 
the environmental diversities was insufficient to guarantee greater stability in the two years of experimentation. The genetic variability observed indicates that the parents used in the experiment differed from each other, suggesting viability of gains through selection from the use of parents with greater frequencies of favorable alleles, an essential characteristic for the formation of new populations that constitute a basis for a breeding program.

The significance of the contrast 'parents vs. $\mathrm{F}_{1}$ ' permits an inference about the average heterosis of diallel crossings, a fact verified only in relation to plant height. For the other characteristics, the two groups behaved in a similar manner, indicating that the merit of the hybrid combinations is strongly associated with the qualities of the commercial hybrids used.

Pfann et al. (2009) verified for grain yield that the treatments $\mathrm{x}$ environments interaction was significant, involving eleven simple hybrids and two environments, in contrast to the lack of significance for this interaction in the case of the average plant and ear heights. Studying the combining abilities of the twelve commercial hybrids in a complete diallel conducted in three locations, Oliboni et al. (2013) found analogous significances to those detected in this study with regard to the 'treatments x environments' interactions for yield, average plant height and average ear height. Amorim and Souza (2005) discuss that commercial simple hybrids still present in the market associate essential characteristics for good agricultural performance, reuniting a high number of already fixed favorable loci with elevated production. Evaluating the combining abilities of partially inbred progeny from commercial maize hybrids, Carvalho et al. (2004) indicated that synthetics derived from simple commercial hybrids show high means and large genetic variability, therefore having large potential for the extraction of inbred lines for hybrid production.

It is possible to verify through the diallel analysis (Table 2) that there is genetic variability between the 96 genotypes that make up the $F_{1}$ group, as well as their interactions with the years of cultivation, for all of the characteristics evaluated. The results indicate the need to unfold the degrees of freedom for genotypes in degrees of freedom for GCA and SCA, along with their respective interactions with the environments.

In general, the variability of the $\hat{g}_{\mathrm{i}}$ indicates that the commercial hybrids used as parents had different contributions in the supply of favorable alleles with additive effects to their progeny. Furthermore, the variability of the $\hat{s}_{\mathrm{ij}}$ indicates hybrid combinations with different performances in relation to what would be expected based only on the GCA effects. However, the significance of the interactions of the $F_{1}$ with the environments suggests a reduction in the correlation between the phenotype and genotype, limiting inferences about the behaviors of specific materials.

In the unfolding of the effects of the treatments on GCA and SCA, significances were verified for the GCA for yield and plant height, in relation to the set of parents from group I. Regarding the ear height, the differences were verified only in group II. The magnitude of the mean squares of the GCA of genotypic group II were greater than those for group I for all of the evaluated traits, suggesting a predominance of greater additive effects for the genotypes from group II.

Various authors report the predominance of additive effects and partial dominance in the genetic control of plant height and ear height (SAWAZAKI et al., 2000; GORGULHO; MIRANDA FILHO, 2001; OLIBONI, 2013). The predominance of the additive effects in the control of grain yield has also stated been by various authors (SANTOS et al., 1985; PINTO et al., 2001; SCAPIM et al., 2002, LOCATELLI et al., 2002; CARVALHO et al., 2004).

The analysis of the estimates for the GCA (Table 3) for the parents from groups I and II relative to productivity revealed that, within group I, the 
30B39, 30B30 and 30K 64 hybrids showed high GCA estimates considering the average environment, as the GCA of group I did not show significance with the environments. In addition to the elevated $\hat{g}_{\mathrm{i}} \mathrm{s}$, these parents were situated between the parents placed in the group with the highest means by the Scott-Knott test (Table 4). It can also be observed that the effects of the GCA were not significant for grain yield within group II, indicating a certain similarity in the contributions of the parents to their progeny. The superior means and higher estimates for $\mathrm{g}_{\mathrm{i}}$ for yield indicate that the populations derived from these parents tend to offer greater perspective of success in the selection of superior inbred lines.

Table 3. Estimates of the effects for the general combining ability $\left(\hat{g}_{\mathrm{i}}\right)$ for yield, plant height and ear height in the two years of experimentation in Sabáudia/PR, Brazil.

\begin{tabular}{|c|c|c|c|c|c|c|}
\hline \multirow{2}{*}{ Hybrids } & \multirow{2}{*}{\multicolumn{2}{|c|}{$\begin{array}{c}\text { Yield } \\
\text { Mean }\end{array}$}} & \multicolumn{2}{|c|}{ Plant Height } & \multicolumn{2}{|c|}{ Ear Height } \\
\hline & & & Season 1 & Season 2 & Season 1 & Season 2 \\
\hline \multicolumn{7}{|c|}{ Group I - Pioneer Hybrids } \\
\hline $30 \mathrm{~F} 35$ & \multicolumn{2}{|c|}{$-0,443$} & $-9,646$ & $-8,707$ & $-1,078$ & $-9,707$ \\
\hline 3021 & \multicolumn{2}{|c|}{$-0,436$} & $-9,820$ & 1,356 & $-8,790$ & $-0,607$ \\
\hline $30 \mathrm{~K} 64$ & \multicolumn{2}{|c|}{0,440} & 4,351 & 8,703 & 8,482 & 7,841 \\
\hline $30 \mathrm{~F} 53$ & \multicolumn{2}{|c|}{$-0,191$} & $-3,900$ & $-8,734$ & $-0,549$ & $-0,489$ \\
\hline P3646 & \multicolumn{2}{|c|}{$-0,133$} & $-2,322$ & 4,782 & $-0,245$ & 5,702 \\
\hline P1630 & \multicolumn{2}{|c|}{0,012} & $-2,878$ & $-1,752$ & $-11,360$ & $-3,503$ \\
\hline 30B39 & \multicolumn{2}{|c|}{0,674} & 9,024 & 24,377 & 6,051 & 19,055 \\
\hline $32 \mathrm{R} 48$ & \multicolumn{2}{|c|}{$-0,033$} & $-1,463$ & $-0,559$ & $-4,994$ & $-1,012$ \\
\hline $32 \mathrm{R} 22 \mathrm{H}$ & \multicolumn{2}{|c|}{$-1,423$} & $-2,074$ & $-2,384$ & $-10,061$ & $-4,02$ \\
\hline P3340 & \multicolumn{2}{|c|}{$-0,338$} & $-4,783$ & $-20,724$ & $-4,786$ & $-11,239$ \\
\hline P30K73 & \multicolumn{2}{|c|}{0,252} & 9,146 & $-0,888$ & 7,994 & $-1,674$ \\
\hline P4285 & \multicolumn{2}{|c|}{0,076} & 5,742 & 0,148 & 5,005 & $-4,615$ \\
\hline P30F36 & \multicolumn{2}{|c|}{0,278} & 3,505 & 3,087 & 4,523 & $-2,397$ \\
\hline 30R50 & \multicolumn{2}{|c|}{0,191} & $-0,385$ & $-6,918$ & 1,741 & $-5,935$ \\
\hline 30B30 & \multicolumn{2}{|c|}{0,553} & 4,557 & 8,103 & 1,745 & 11,541 \\
\hline $30 \mathrm{~F} 80$ & \multicolumn{2}{|c|}{0,520} & 0,946 & 0,111 & 6,325 & 1,058 \\
\hline $\operatorname{DP}\left(\hat{g}_{\mathrm{i}}-\hat{g}_{\mathrm{i}}{ }^{\prime}\right)$ & \multicolumn{2}{|c|}{-} & 3,695 & 4,08 & 3,235 & 3,512 \\
\hline \multicolumn{7}{|c|}{ Group II - Agroceres/Monsanto Hybrids } \\
\hline Hybrids & Season 1 & Season 2 & Season 1 & Season 2 & Season 1 & Season 2 \\
\hline AG8088 & 0,111 & 0,156 & 1,93 & 0,644 & $-3,477$ & 3,443 \\
\hline AG7088 & 0,730 & 0,412 & 4,741 & 5,572 & 10,027 & 5,846 \\
\hline AG9045 & $-0,872$ & $-0,008$ & $-6,461$ & 5,165 & $-5,847$ & 0,478 \\
\hline AG8021 & 0,700 & $-0,129$ & 12,603 & 4,555 & 12,096 & 4,429 \\
\hline AG9040 & $-0,304$ & $-0,476$ & $-10,28$ & $-3,957$ & $-8,732$ & $-6,454$ \\
\hline AG7010 & $-0,365$ & 0,045 & $-2,527$ & $-11,979$ & $-4,065$ & $-7,743$ \\
\hline $\mathrm{DP}\left(\hat{g}_{\mathrm{i}}-\hat{g}_{\mathrm{i}}\right)$ & 0,177 & 0,275 & 2,263 & 2,498 & 1,981 & 2,151 \\
\hline
\end{tabular}

The P1630 and 30F53 parents can be recommended in relation to plant height for use in breeding programs that seek the formation of compounds for intrapopulation breeding, taking advantage of the effects of GCA, as these parents were included in the groups with lower means by 
the Scott-Knott test and negative $\mathrm{g}_{\mathrm{i}}$ estimates in both years of experimentation. Within the second group of parents, in an analogous manner to that verified for productivity, there was no significance of the effects of GCA, permitting the inference that parents from Group II did not differ from each other with regard to their ability to provide favorable alleles to their progeny, to promote a reduction in the average height of their progeny. Although the aforementioned parents were simple hybrids and the results demonstrate complex interactions between height and environments, the above hybrids are likely carriers of favorable alleles for plant height reduction in both environments.

Table 4. Estimates of the specific combining ability $\left(\hat{\mathbf{s}}_{\mathrm{ij}}\right)$ for maize yield in the average environment and yield $\left(\mathrm{t}\right.$ ha ${ }^{-}$ ${ }^{1}$ ) in year 1 (2011/2012), considering 22 parents, 96 hybrid combinations and 4 controls evaluated in Sabáudia/PR, Brazil.

\begin{tabular}{|c|c|c|c|c|c|c|c|c|c|c|c|c|c|}
\hline & \multicolumn{2}{|c|}{ AG8088 } & \multicolumn{2}{|c|}{ AG7088 } & \multicolumn{2}{|c|}{ AG9045 } & \multicolumn{2}{|c|}{ AG8021 } & \multicolumn{2}{|c|}{ AG9040 } & \multicolumn{2}{|c|}{ AG7010 } & \multirow{2}{*}{ Yield } \\
\hline & Yield & $\hat{\mathbf{s}}_{\mathrm{ij}}$ & Yield & $\hat{\mathbf{s}}_{\mathrm{ij}}$ & Yield & $\hat{\mathbf{s}}_{\mathrm{ij}}$ & Yield & $\hat{\mathbf{s}}_{\mathrm{ij}}$ & Yield & $\hat{\mathbf{s}}_{\mathrm{ij}}$ & Yield & $\hat{\mathbf{s}}_{\mathrm{ij}}$ & \\
\hline $30 \mathrm{~F} 35$ & $6,81 b$ & 0,39 & $6,58 b$ & $-0,63$ & $6,51 b$ & 1,06 & $6,83 b$ & $-0,92$ & $5,39 b$ & $-0,31$ & $6,58 b$ & 0,41 & $7,76 \mathrm{a}$ \\
\hline 3021 & $5,66 \mathrm{~b}$ & $-0,61$ & $6,90 b$ & 0,14 & $5,79 b$ & 0,49 & $7,41 \mathrm{a}$ & 0,37 & $7,53 \mathrm{a}$ & 0,73 & $3,68 \mathrm{~d}$ & $-1,13$ & $2,13 \mathrm{e}$ \\
\hline $30 \mathrm{~K} 64$ & $6,86 b$ & 0,44 & $6,67 b$ & $-0,08$ & $6,01 b$ & $-0,57$ & $7,54 \mathrm{a}$ & 0,15 & $6,74 b$ & $-0,49$ & $7,56 \mathrm{a}$ & 0,55 & $7,19 \mathrm{a}$ \\
\hline $30 \mathrm{~F} 53$ & $6,61 b$ & 0,23 & $7,37 \mathrm{a}$ & 0,59 & $5,67 \mathrm{~b}$ & 0,67 & $7,48 \mathrm{a}$ & 0,06 & $6,21 b$ & 0,18 & $4,38 \mathrm{c}$ & $-1,74$ & $8,23 \mathrm{a}$ \\
\hline P3646 & $6,63 b$ & 0,48 & $6,40 \mathrm{~b}$ & $-0,62$ & $6,53 b$ & $-0,26$ & $7,10 \mathrm{~b}$ & $-1,48$ & $6,96 b$ & 0,38 & $7,94 a$ & 1,51 & $8,17 \mathrm{a}$ \\
\hline P1630 & $6,88 b$ & $-0,42$ & $8,80 \mathrm{a}$ & 0,63 & $5,86 \mathrm{~b}$ & $-0,00$ & $8,38 \mathrm{a}$ & 0,20 & $7,49 a$ & $-0,30$ & $6,37 b$ & $-0,11$ & $7,36 \mathrm{a}$ \\
\hline 30B39 & $8,17 \mathrm{a}$ & 0,53 & $7,68 \mathrm{a}$ & $-0,66$ & $7,30 \mathrm{a}$ & 0,66 & $8,21 \mathrm{a}$ & $-0,52$ & $6,86 \mathrm{~b}$ & 0,21 & $7,73 \mathrm{a}$ & $-0,22$ & $8,05 \mathrm{a}$ \\
\hline $32 \mathrm{R} 48$ & $6,67 b$ & $-0,89$ & $8,66 \mathrm{a}$ & 0,51 & $4,49 c$ & $-0,54$ & $7,72 \mathrm{a}$ & 0,65 & $6,82 b$ & $-0,07$ & $5,19 \mathrm{c}$ & $-0,46$ & $4,04 \mathrm{c}$ \\
\hline $30 \mathrm{R} 22$ & $4,58 \mathrm{c}$ & $-0,48$ & $5,99 \mathrm{~b}$ & 0,55 & $4,35 c$ & $-0,39$ & $5,70 \mathrm{~b}$ & $-0,25$ & $4,22 \mathrm{c}$ & $-0,63$ & $6,56 \mathrm{~b}$ & 1,21 & $5,41 \mathrm{c}$ \\
\hline P3340 & $8,03 \mathrm{a}$ & 0,19 & $8,04 \mathrm{a}$ & 0,54 & $5,75 b$ & $-0,18$ & $7,38 \mathrm{a}$ & 0,67 & $6,10 \mathrm{~b}$ & $-0,03$ & $4,92 \mathrm{c}$ & $-1,20$ & $8,58 \mathrm{a}$ \\
\hline P30K 73 & $6,68 b$ & $-0,23$ & $7,87 \mathrm{a}$ & 0,10 & $7,09 \mathrm{~b}$ & 0,31 & $7,61 \mathrm{a}$ & 0,26 & $6,09 \mathrm{~b}$ & $-0,73$ & $6,87 \mathrm{~b}$ & 0,27 & $6,99 b$ \\
\hline P4285 & $6,79 b$ & $-0,47$ & $7,83 a$ & 0,25 & $6,17 \mathrm{~b}$ & $-0,15$ & $8,20 \mathrm{a}$ & 0,50 & $6,66 \mathrm{~b}$ & 0,19 & $6,00 \mathrm{~b}$ & $-0,32$ & $7,91 \mathrm{a}$ \\
\hline P30F36 & $7,49 \mathrm{a}$ & 0,33 & $7,38 \mathrm{a}$ & $-0,32$ & $5,93 b$ & $-0,78$ & $8,00 \mathrm{a}$ & $-0,06$ & $6,75 b$ & 0,29 & $7,78 \mathrm{a}$ & 0,53 & $5,79 \mathrm{~b}$ \\
\hline 30R50 & $7,24 \mathrm{a}$ & $-0,41$ & $7,91 \mathrm{a}$ & 0,08 & $5,24 \mathrm{c}$ & $-0,17$ & $6,99 b$ & 0,19 & $7,11 \mathrm{~b}$ & 0,84 & $6,26 \mathrm{~b}$ & $-0,53$ & $5,16 \mathrm{c}$ \\
\hline $30 \mathrm{~B} 30$ & $7,91 \mathrm{a}$ & $-0,24$ & $7,69 a$ & $-0,64$ & $5,75 b$ & $-0,63$ & $8,11 \mathrm{a}$ & 0,33 & $6,44 b$ & 0,24 & $7,99 a$ & 0,93 & $6,41 \mathrm{~b}$ \\
\hline $30 \mathrm{~F} 80$ & $7,50 \mathrm{a}$ & 0,35 & $8,15 \mathrm{a}$ & $-0,45$ & $6,38 \mathrm{~b}$ & 0,48 & $7,22 \mathrm{a}$ & $-0,17$ & $6,53 \mathrm{~b}$ & $-0,52$ & $7,12 \mathrm{~b}$ & 0,31 & $5,22 \mathrm{c}$ \\
\hline Yield. & $8,25 a$ & - & $8,09 a$ & - & $5,62 b$ & - & $6,62 b$ & - & $6,18 \mathrm{~b}$ & - & $2,86 \mathrm{e}$ & - & - \\
\hline \multicolumn{14}{|c|}{ Controls } \\
\hline & Cargo & & & & & & & Celeror & & & & enta & \\
\hline & $6,69 \mathrm{~b}$ & & & & & & & $7,53 \mathrm{a}$ & & & & $34 c$ & \\
\hline
\end{tabular}

Means followed by the same letter belong to the same group according to the Scott Knott method at a 5\% probability.

The GCA estimates for parents from the first group did not differ significantly from each other in relation to ear height, indicating a similar behavior to the parents. Within group II, the parents that promoted the largest reductions in ear height were the AG9040 and AG7010 hybrids, given their high-magnitude negative estimates in both years.
Additionally, AG9040 and AG7010 were also the parents included in the groups with the lowest means for this trait and were thus identified as promising for breeding programs.

The formation of compounds for intrapopulation breeding constitutes one of the alternatives for obtaining superior genotypes (SCAPIM et al., 
2002). Considering that the choice of materials for the formation of compounds must be performed based on the GCA of the parents involved, the results from this study permit the inference that the compounds formed by the hybrids 30B39, 30B30 and 30K64, with high GCA for yield, with the AG9040 and AG7010 hybrids, which show GCA fit for the reduction of the average ear height, would be promising. Another possibility would be the formation of compounds involving the parents 30B39, 30B30 and 30K64 for yield and the P1630 hybrid for reduction of ear height, with subsequent intrapopulation recurrent selection.

According to Cruz et al. (2007), the selection of the most promising hybrid combinations must be made based on estimates of the SCA that most favor the trait in question but that involve at least one parent with a high GCA. In this study, some combinations were highlighted through SCA effects. Considering only the parents selected based on the GCA for grain yield (30B39, 30K64 and 30B30, according to Tables 4 and 5), the hybrid combinations with the largest $\hat{s}_{\mathrm{ij}}$ values were 30B39 x AG9045, 30B39 x AG8088, 30B30 x AG7010, 30K64 x AG8088 and 30K64 x AG7010. Thus, it is probable that, in these crossings, genetic complementation occurred between the parents, causing an increase in the mean of the evaluated characteristic, as a consequence of the effects of dominance and epistasis.

Table 5. Estimates of the specific combining ability $\left(\hat{\boldsymbol{S}}_{\mathrm{ij}}\right)$ for maize yield in the average environment and yield $\left(\mathrm{t} \mathrm{ha}^{-1}\right)$ in year 2 (2012/2013) for 22 parents, 96 hybrid combinations and 4 controls evaluated in Sabáudia/PR, Brazil.

\begin{tabular}{|c|c|c|c|c|c|c|c|c|c|c|c|c|c|}
\hline & \multicolumn{2}{|c|}{ AG8088 } & \multicolumn{2}{|c|}{ AG7088 } & \multicolumn{2}{|c|}{ AG9045 } & \multicolumn{2}{|c|}{ AG8021 } & \multicolumn{2}{|c|}{ AG9040 } & \multicolumn{2}{|c|}{ AG7010 } & \multirow{2}{*}{ Yield } \\
\hline & Yield & $\hat{\mathbf{s}}_{\mathrm{ij}}$ & Yield & $\hat{\mathbf{s}}_{\mathrm{ij}}$ & Yield & $\hat{\mathbf{s}}_{\mathrm{ij}}$ & Yield & $\hat{\mathbf{s}}_{\mathrm{ij}}$ & Yield & $\hat{\mathbf{s}}_{\mathrm{ij}}$ & Yield & $\hat{\mathbf{s}}_{\mathrm{ij}}$ & \\
\hline $30 \mathrm{~F} 35$ & $8,13 \mathrm{a}$ & 0,39 & $7,19 \mathrm{a}$ & $-0,63$ & $8,64 \mathrm{a}$ & 1,06 & $5,79 \mathrm{c}$ & $-0,92$ & $7,10 \mathrm{~b}$ & $-0,31$ & $7,82 \mathrm{a}$ & 0,41 & $10,48 \mathrm{a}$ \\
\hline 3021 & $7,29 b$ & $-0,61$ & $8,44 a$ & 0,14 & $8,23 a$ & 0,49 & $7,78 \mathrm{a}$ & 0,37 & $7,06 b$ & 0,73 & $7,63 b$ & $-1,13$ & $7,04 b$ \\
\hline $30 \mathrm{~K} 64$ & $9,96 \mathrm{a}$ & 0,44 & $9,96 a$ & $-0,08$ & $7,63 b$ & $-0,57$ & $9,00 \mathrm{a}$ & 0,15 & $7,15 b$ & $-0,49$ & $8,88 \mathrm{a}$ & 0,55 & $9,29 a$ \\
\hline $30 F 53$ & $8,52 \mathrm{a}$ & 0,23 & $9,36 a$ & 0,59 & $9,20 \mathrm{a}$ & 0,67 & $7,61 b$ & 0,06 & $7,78 \mathrm{a}$ & 0,18 & $6,21 \mathrm{c}$ & $-1,74$ & $6,71 b$ \\
\hline P3646 & $9,11 \mathrm{a}$ & 0,48 & $7,46 b$ & $-0,62$ & $6,58 b$ & $-0,26$ & $5,01 \mathrm{c}$ & $-1,48$ & $7,54 b$ & 0,38 & $9,88 \mathrm{a}$ & 1,51 & $11,00 \mathrm{a}$ \\
\hline P1630 & $7,35 b$ & $-0,42$ & $8,43 a$ & 0,63 & $8,05 \mathrm{a}$ & $-0,00$ & $7,42 b$ & 0,20 & $5,93 c$ & $-0,30$ & $7,89 a$ & $-0,11$ & $7,06 \mathrm{~b}$ \\
\hline 30B39 & $9,30 \mathrm{a}$ & 0,53 & $8,26 a$ & $-0,66$ & $9,28 \mathrm{a}$ & 0,66 & $7,44 b$ & $-0,52$ & $8,92 \mathrm{a}$ & 0,21 & $8,92 b$ & $-0,22$ & $9,36 \mathrm{a}$ \\
\hline $32 \mathrm{R} 48$ & $8,13 \mathrm{a}$ & $-0,89$ & $8,24 a$ & 0,51 & $8,27 \mathrm{a}$ & $-0,54$ & $8,88 \mathrm{a}$ & 0,65 & $6,96 b$ & $-0,07$ & $8,28 \mathrm{a}$ & $-0,46$ & $7,75 a$ \\
\hline 30R22 & $6,65 b$ & $-0,48$ & $8,19 a$ & 0,55 & $5,92 \mathrm{c}$ & $-0,39$ & $6,24 c$ & $-0,25$ & $5,67 \mathrm{c}$ & $-0,63$ & $7,49 b$ & 1,21 & $7,02 b$ \\
\hline P3340 & $6,73 b$ & 0,19 & $8,30 \mathrm{a}$ & 0,54 & $7,11 \mathrm{~b}$ & $-0,18$ & $8,66 \mathrm{a}$ & 0,67 & $7,16 b$ & $-0,03$ & $6,46 b$ & $-1,20$ & $9,58 \mathrm{a}$ \\
\hline P30K73 & $8,41 \mathrm{a}$ & $-0,23$ & $8,76 a$ & 0,10 & $7,95 a$ & 0,31 & $8,77 \mathrm{a}$ & 0,26 & $6,96 b$ & $-0,73$ & $8,64 \mathrm{a}$ & 0,27 & $9,42 \mathrm{a}$ \\
\hline P4285 & $7,46 b$ & $-0,47$ & $8,76 a$ & 0,25 & $7,57 b$ & $-0,15$ & $8,32 \mathrm{a}$ & 0,50 & $7,89 \mathrm{a}$ & 0,19 & $7,96 \mathrm{a}$ & $-0,32$ & $9,82 \mathrm{a}$ \\
\hline P30F36 & $8,78 \mathrm{a}$ & 0,33 & $8,45 \mathrm{a}$ & $-0,32$ & $6,97 b$ & $-0,78$ & $7,78 \mathrm{a}$ & $-0,06$ & $8,40 \mathrm{a}$ & 0,29 & $8,30 \mathrm{a}$ & 0,53 & $7,24 b$ \\
\hline $30 \mathrm{R} 50$ & $7,36 \mathrm{a}$ & $-0,41$ & $8,56 a$ & 0,08 & $8,70 \mathrm{a}$ & $-0,17$ & $9,12 \mathrm{a}$ & 0,19 & $8,96 \mathrm{a}$ & 0,84 & $7,51 b$ & $-0,53$ & $7,65 b$ \\
\hline 30B30 & $7,76 b$ & $-0,24$ & $8,06 a$ & $-0,64$ & $7,99 a$ & $-0,63$ & $9,02 \mathrm{a}$ & 0,33 & $9,17 \mathrm{a}$ & 0,24 & $9,46 a$ & 0,93 & $8,49 a$ \\
\hline $30 \mathrm{~F} 80$ & $9,29 \mathrm{a}$ & 0,35 & $7,92 \mathrm{a}$ & $-0,45$ & $9,53 \mathrm{a}$ & 0,48 & $8,83 \mathrm{a}$ & $-0,17$ & $7,48 \mathrm{~b}$ & $-0,52$ & $9,01 \mathrm{a}$ & 0,31 & $5,97 \mathrm{c}$ \\
\hline Yield. & $8,86 a$ & - & $8,18 \mathrm{a}$ & - & $9,10 \mathrm{a}$ & - & $7,47 \mathrm{~b}$ & - & $7,43 b$ & - & $7,79 a$ & - & - \\
\hline \multicolumn{14}{|c|}{ Controls } \\
\hline & Cargo & & & & & & & Celeror & & & & enta & \\
\hline & 7,09a & & & & & & & $8,13 \mathrm{a}$ & & & & $26 \mathrm{a}$ & \\
\hline
\end{tabular}

Means followed by the same letter belong to the same group according to the Scott Knott method at a 5\% probability. 
The 30F53 and P1630 hybrids were identified as superior parents in relation to plant height, given the GCA values estimated by their $\hat{g}_{\mathrm{i}} \mathrm{s}$ in both years. The combinations 30F53 x AG9045, 30F53 $\mathrm{x}$ AG7010 and P1630 x AG7010 show genetic complementation favorable to the reduction of the phenotypic values of the trait in question (Tables 6 and 7).

The commercial hybrids AG9040 and AG7010 showed the lowest GCA estimates for ear height (Tables 8 and 9). Their hybrid combinations 30R50 x AG7010, P1630 x AG7010, 3021 x AG7010, 30B39 x AG9040, 30F80 x AG9040 and 30R50 $\mathrm{x}$ AG9040 showed the highest levels of desired genetic complementation, in the direction of reducing ear height.
The results for $\hat{u}+\hat{a}$ (Table 10) indicate that the AG8021, P1630, 3021, AG7010, P4285, AG7088 and $30 \mathrm{~B} 39$ hybrids were particularly promising for the extraction of more productive inbred lines. Analogously, the P1630 and AG7010 hybrids were highlighted in plant height in the first year (2011/2012), as were AG7088, AG9045, AG8021 and $30 \mathrm{~B} 30$ in the second year of experimentation (2012/2013). In relation to ear height, the parents 30B39, AG9045 and AG7010 performed differently in the first year of evaluation, and relevant roles were suited to the parents 30B39, AG7088 and AG8021 in the second year of experimentation. Additionally, the results permit the inference that advanced generations obtained from the 30B39 hybrid may be promising for the selection of recombinants that combine high yield and low ear height.

Table 6. Estimates of the specific combining ability $\left(\widehat{\mathbf{s}}_{\mathrm{ij}}\right)$ and plant height means $(\mathrm{m})$ in year $1(2011 / 2012)$ for 22 parents, 96 hybrid combinations and 4 controls evaluated in Sabáudia/PR, Brazil.

\begin{tabular}{|c|c|c|c|c|c|c|c|c|c|c|c|c|c|}
\hline & \multicolumn{2}{|c|}{ AG8088 } & \multicolumn{2}{|c|}{ AG7088 } & \multicolumn{2}{|c|}{ AG9045 } & \multicolumn{2}{|c|}{ AG8021 } & \multicolumn{2}{|c|}{ AG9040 } & \multicolumn{2}{|c|}{ AG7010 } & \multirow{2}{*}{ PH } \\
\hline & PH & $\hat{\mathbf{s}}_{\mathrm{ij}}$ & PH & $\hat{\mathbf{s}}_{\mathrm{ij}}$ & PH & $\hat{\mathbf{s}}_{\mathrm{ij}}$ & PH & $\hat{\mathbf{s}}_{\mathrm{ij}}$ & PH & $\hat{\mathbf{s}}_{\mathrm{ij}}$ & PH & $\hat{\mathbf{s}}_{\mathrm{ij}}$ & \\
\hline $30 \mathrm{~F} 35$ & $2,40 b$ & $-1,86$ & $2,36 b$ & $-8,52$ & $2,36 b$ & 2,36 & $2,57 \mathrm{a}$ & 4,22 & $2,38 b$ & 7,62 & $2,34 \mathrm{c}$ & $-4,01$ & $2,64 \mathrm{a}$ \\
\hline 3021 & $2,36 b$ & $-6,43$ & $2,41 b$ & $-3,36$ & $2,41 b$ & 7,51 & $2,53 a$ & 0,50 & $2,33 \mathrm{c}$ & 3,09 & $2,33 b$ & $-1,31$ & $2,33 \mathrm{c}$ \\
\hline $30 \mathrm{~K} 64$ & $2,60 \mathrm{a}$ & 3,48 & $2,48 b$ & $-11,06$ & $2,45 b$ & $-2,25$ & $2,64 a$ & $-2,89$ & $2,51 b$ & 7,17 & $2,57 \mathrm{a}$ & 5,53 & $2,65 \mathrm{a}$ \\
\hline $30 \mathrm{~F} 53$ & $2,47 b$ & $-0,81$ & $2,55 \mathrm{a}$ & 4,68 & $2,40 \mathrm{~b}$ & $-0,97$ & $2,60 \mathrm{a}$ & 1,04 & $2,31 \mathrm{c}$ & $-4,69$ & $2,42 b$ & $-1,18$ & $2,46 b$ \\
\hline P3646 & $2,52 \mathrm{a}$ & 2,37 & $2,45 b$ & $-7,58$ & $2,39 b$ & $-4,61$ & $2,59 \mathrm{a}$ & $-1,91$ & $2,39 b$ & 1,89 & $2,55 \mathrm{a}$ & 9,84 & $2,41 b$ \\
\hline P1630 & $2,46 b$ & $-2,61$ & $2,60 \mathrm{a}$ & 8,37 & $2,46 b$ & 5,08 & $2,55 \mathrm{a}$ & $-4,84$ & $2,42 b$ & 5,66 & $2,33 \mathrm{c}$ & $-11,6$ & $2,45 b$ \\
\hline 30B39 & $2,57 \mathrm{a}$ & $-4,08$ & $2,53 \mathrm{a}$ & $-10,29$ & $2,50 \mathrm{~b}$ & $-2,73$ & $2,78 \mathrm{a}$ & 6,20 & $2,47 b$ & $-1,64$ & $2,69 a$ & 12,55 & $2,76 a$ \\
\hline $32 \mathrm{R} 48$ & $2,51 \mathrm{~b}$ & 0,85 & $2,61 \mathrm{a}$ & 0,68 & $2,37 b$ & $-5,19$ & $2,61 \mathrm{a}$ & 0,29 & $2,40 \mathrm{~b}$ & 1,63 & $2,41 b$ & $-5,27$ & $2,31 \mathrm{c}$ \\
\hline 30R22 & $2,50 \mathrm{~b}$ & $-0,12$ & $2,53 \mathrm{a}$ & 0,74 & $2,41 b$ & $-0,02$ & $2,66 a$ & 5,99 & $2,27 \mathrm{c}$ & $-10,18$ & $2,27 b$ & 3,59 & $2,52 \mathrm{a}$ \\
\hline P3340 & $2,53 \mathrm{a}$ & 5,78 & $2,56 a$ & 6,36 & $2,39 b$ & 0,15 & $2,53 a$ & $-4,36$ & $2,28 \mathrm{c}$ & $-6,35$ & $2,41 b$ & $-1,59$ & $2,52 \mathrm{a}$ \\
\hline P30K73 & $2,62 \mathrm{a}$ & 0,64 & $2,63 a$ & $-0,99$ & $2,63 b$ & $-3,84$ & $2,78 \mathrm{a}$ & 6,34 & $2,47 b$ & $-1,50$ & $2,56 a$ & $-0,64$ & $2,57 \mathrm{a}$ \\
\hline P4285 & $2,55 \mathrm{a}$ & $-2,74$ & $2,63 a$ & 2,40 & $2,48 b$ & $-0,88$ & $2,75 a$ & 6,68 & 2,41 & $-4,47$ & $2,52 \mathrm{a}$ & $-0,96$ & $2,65 \mathrm{a}$ \\
\hline P30F36 & $2,58 \mathrm{a}$ & 2,54 & $2,62 \mathrm{a}$ & 3,87 & $2,48 b$ & 1,01 & $2,63 a$ & $-3,37$ & 2,40 & $-2,89$ & $2,50 \mathrm{~b}$ & $-1,19$ & $2,45 b$ \\
\hline $30 \mathrm{R} 50$ & $2,53 a$ & 1,76 & $2,59 a$ & 5,25 & $2,50 \mathrm{~b}$ & 7,37 & $2,52 \mathrm{a}$ & $-9,36$ & $2,41 b$ & 1,70 & $2,40 \mathrm{~b}$ & $-6,45$ & $2,19 \mathrm{c}$ \\
\hline 30B30 & $2,57 \mathrm{a}$ & 0,64 & $2,64 a$ & 4,42 & $2,38 b$ & $-9,68$ & $2,65 \mathrm{a}$ & $-2,40$ & $2,49 b$ & 4,74 & $2,54 \mathrm{a}$ & 2,27 & $2,43 b$ \\
\hline $30 \mathrm{~F} 80$ & $2,53 a$ & 0,32 & $2,54 \mathrm{a}$ & $-1,97$ & $2,49 b$ & 4,73 & $2,62 \mathrm{a}$ & $-1,86$ & $2,39 b$ & $-1,77$ & $2,49 \mathrm{~b}$ & 0,49 & $2,25 \mathrm{c}$ \\
\hline $\mathrm{PH}$ & $2,34 \mathrm{c}$ & - & $2,37 \mathrm{~b}$ & - & $2,24 \mathrm{c}$ & - & $2,61 \mathrm{a}$ & - & $2,27 \mathrm{c}$ & - & $2,36 \mathrm{~b}$ & - & \\
\hline \multicolumn{14}{|c|}{ Controls } \\
\hline & Cargo & & \multicolumn{4}{|c|}{ Status } & \multicolumn{3}{|c|}{ Celeron } & \multicolumn{4}{|c|}{ Penta } \\
\hline & $2,19 \mathrm{c}$ & & \multicolumn{4}{|c|}{$2,50 \mathrm{~b}$} & \multicolumn{3}{|c|}{$2,31 \mathrm{c}$} & \multicolumn{4}{|c|}{$2,19 \mathrm{c}$} \\
\hline
\end{tabular}

Means followed by the same letter belong to the same group according to the Scott Knott method at a $5 \%$ probability. 
Table 7. Estimates of the specific combining ability $\left(\widehat{\mathbf{s}}_{\mathrm{ij}}\right)$ and plant height means $(\mathrm{m})$ in year $2(2012 / 2013)$ for 22 parents, 96 hybrid combinations and 4 controls evaluated in Sabáudia/PR, Brazil.

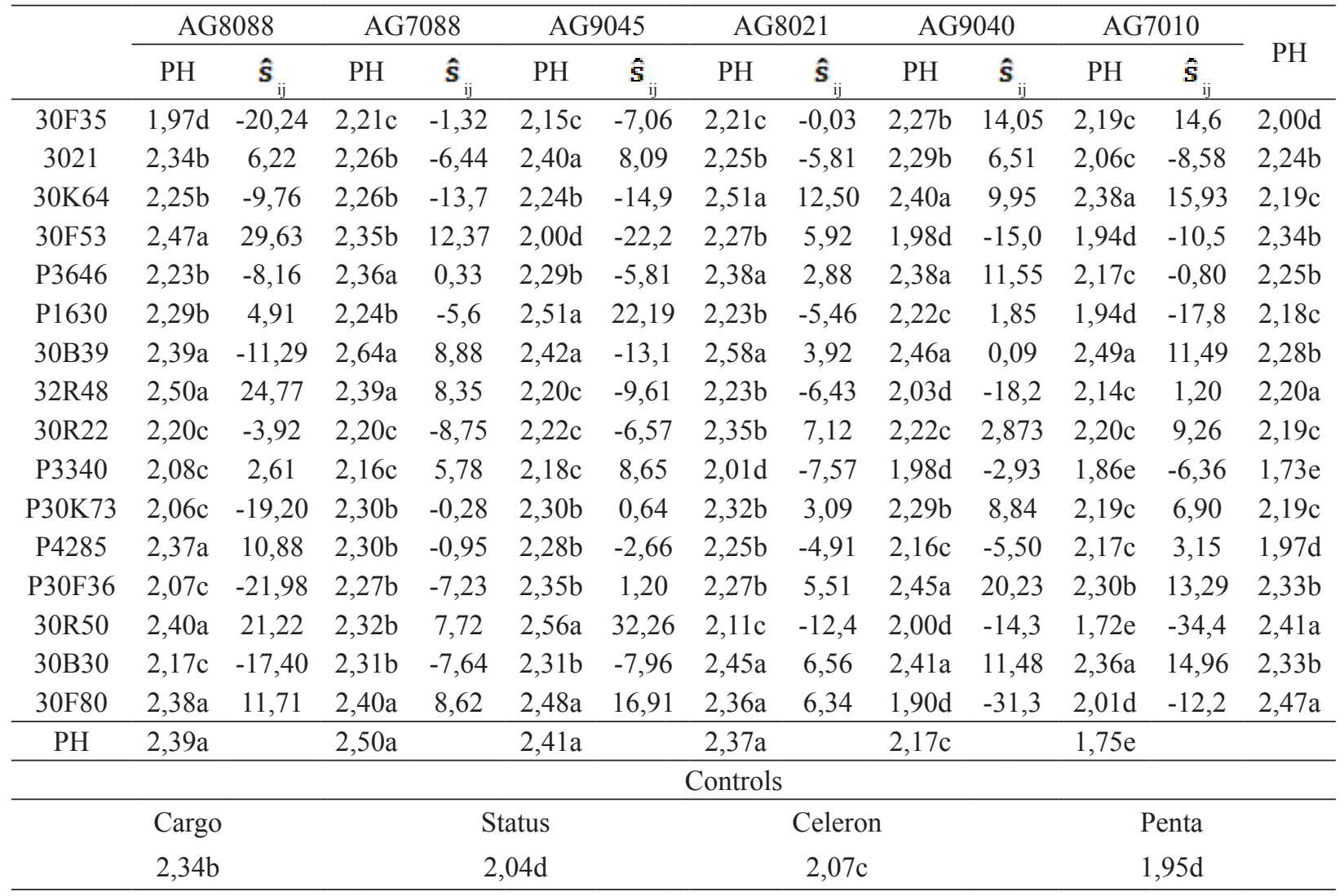

Means followed by the same letter belong to the same group according to the Scott Knott method at a 5\% probability.

Table 8. Estimates of the specific combining ability $\left(\hat{\mathbf{s}}_{\mathrm{ij}}\right)$ and ear height means $(\mathrm{m})$ in year $1(2011 / 2012)$ for 22 parents, 96 hybrid combinations and 4 controls in Sabáudia/PR, Brazil.

\begin{tabular}{|c|c|c|c|c|c|c|c|c|c|c|c|c|c|}
\hline & \multicolumn{2}{|c|}{ AG8088 } & \multicolumn{2}{|c|}{ AG7088 } & \multicolumn{2}{|c|}{ AG9045 } & \multicolumn{2}{|c|}{ AG8021 } & \multicolumn{2}{|c|}{ AG9040 } & \multicolumn{2}{|c|}{ AG7010 } & \multirow{2}{*}{ EH } \\
\hline & $\mathrm{EH}$ & $\hat{\mathbf{s}}_{\mathrm{ij}}$ & $\mathrm{EH}$ & $\hat{\mathbf{s}}_{\mathrm{ij}}$ & $\mathrm{EH}$ & $\hat{\mathbf{s}}_{\mathrm{ij}}$ & $\mathrm{EH}$ & $\hat{\mathbf{s}}_{\mathrm{ij}}$ & $\mathrm{EH}$ & $\hat{\mathbf{s}}_{\mathrm{ij}}$ & $\mathrm{EH}$ & $\hat{\mathbf{s}}_{\mathrm{ij}}$ & \\
\hline $30 \mathrm{~F} 35$ & $1,38 \mathrm{c}$ & $-2,25$ & $1,46 b$ & $-7,14$ & $1,39 \mathrm{c}$ & 1,02 & $1,68 \mathrm{a}$ & 12,47 & $1,34 \mathrm{c}$ & $-0,63$ & $1,36 \mathrm{c}$ & $-3,47$ & $1,60 \mathrm{a}$ \\
\hline 3021 & $1,29 \mathrm{c}$ & $-2,82$ & $1,38 \mathrm{c}$ & $-7,46$ & $1,36 \mathrm{c}$ & 6,34 & $1,49 b$ & 1,50 & $1,31 \mathrm{c}$ & 4,09 & $1,30 \mathrm{c}$ & $-1,66$ & $1,41 \mathrm{c}$ \\
\hline $30 \mathrm{~K} 64$ & $1,55 \mathrm{a}$ & 5,66 & $1,59 a$ & $-3,81$ & $1,43 b$ & $-3,97$ & $1,66 \mathrm{a}$ & 1,22 & $1,45 b$ & 1,03 & $1,49 b$ & $-0,13$ & $1,58 \mathrm{a}$ \\
\hline $30 F 53$ & $1,37 \mathrm{c}$ & $-4,00$ & $1,56 a$ & 2,18 & $1,33 \mathrm{c}$ & $-4,83$ & $1,60 \mathrm{a}$ & 3,66 & $1,39 \mathrm{c}$ & 3,74 & $1,39 \mathrm{c}$ & $-0,75$ & $1,45 \mathrm{~b}$ \\
\hline P3646 & $1,40 \mathrm{c}$ & $-1,07$ & $1,52 \mathrm{~b}$ & $-2,21$ & $1,38 \mathrm{c}$ & $-0,71$ & $1,53 \mathrm{~b}$ & $-3,84$ & $1,41 \mathrm{c}$ & 5,13 & $1,43 b$ & 2,71 & $1,45 \mathrm{~b}$ \\
\hline P1630 & $1,21 \mathrm{~d}$ & $-9,07$ & $1,46 \mathrm{~b}$ & 2,53 & $1,33 \mathrm{c}$ & 5,93 & $1,42 b$ & $-3,49$ & $1,31 \mathrm{c}$ & 6,59 & $1,27 \mathrm{c}$ & $-2,49$ & $1,21 d$ \\
\hline 30B39 & $1,46 \mathrm{~b}$ & $-1,14$ & $1,54 \mathrm{~b}$ & $-6,86$ & $1,41 b$ & $-3,28$ & $1,70 \mathrm{a}$ & 6,92 & $1,39 \mathrm{c}$ & 6,92 & $1,54 \mathrm{~b}$ & 7,61 & $1,71 \mathrm{a}$ \\
\hline $32 \mathrm{R} 48$ & $1,40 \mathrm{c}$ & 3,70 & $1,44 \mathrm{~b}$ & $-5,52$ & $1,35 \mathrm{c}$ & 1,62 & $1,53 b$ & 0,95 & $1,32 \mathrm{c}$ & 1,45 & $1,33 \mathrm{c}$ & $-2,21$ & $1,26 \mathrm{c}$ \\
\hline $30 \mathrm{R} 22$ & $1,31 \mathrm{c}$ & $-0,23$ & $1,39 \mathrm{c}$ & $-5,96$ & $1,30 \mathrm{c}$ & 0,95 & $1,30 \mathrm{~b}$ & 1,15 & $1,25 \mathrm{c}$ & $-0,28$ & $1,35 \mathrm{c}$ & 4,37 & $1,32 \mathrm{c}$ \\
\hline P3340 & $1,44 \mathrm{~b}$ & 7,45 & $1,50 \mathrm{~b}$ & $-0,10$ & $1,37 \mathrm{c}$ & 3,29 & $1,48 b$ & $-3,63$ & $1,23 d$ & $-7,71$ & $1,36 \mathrm{c}$ & 0,70 & $1,47 \mathrm{~b}$ \\
\hline P30K73 & $1,56 \mathrm{a}$ & 6,49 & $1,67 \mathrm{a}$ & 4,10 & $1,44 b$ & $-2,72$ & $1,63 a$ & $-1,69$ & $1,47 \mathrm{~b}$ & 2,70 & $1,40 \mathrm{c}$ & $-8,88$ & $1,52 b$ \\
\hline P4285 & $1,38 \mathrm{c}$ & $-8,38$ & $1,65 \mathrm{a}$ & 5,31 & $1,44 b$ & 0,37 & $1,66 \mathrm{a}$ & 3,86 & $1,66 \mathrm{~b}$ & 1,87 & $1,42 b$ & $-3,04$ & $1,58 \mathrm{a}$ \\
\hline
\end{tabular}


Continuation

\begin{tabular}{|c|c|c|c|c|c|c|c|c|c|c|c|c|c|}
\hline P30F36 & $1,48 b$ & 2,54 & $1,67 \mathrm{a}$ & 8,06 & $1,46 b$ & 2,47 & $1,50 \mathrm{~b}$ & $-11,06$ & $1,39 \mathrm{c}$ & $-1,67$ & $1,45 b$ & $-0,34$ & $1,46 \mathrm{~b}$ \\
\hline 30R50 & $1,48 b$ & 5,36 & $1,61 \mathrm{a}$ & 4,89 & $1,47 b$ & 6,62 & $1,49 b$ & $-9,88$ & $1,33 \mathrm{c}$ & $-4,37$ & $1,40 \mathrm{c}$ & $-2,63$ & $1,39 \mathrm{~b}$ \\
\hline 30B30 & $1,39 \mathrm{c}$ & $-3,43$ & $1,66 a$ & 9,17 & $1,28 \mathrm{c}$ & $-12,2$ & $1,60 \mathrm{a}$ & 1,71 & $1,35 \mathrm{c}$ & $-3,06$ & $1,50 \mathrm{~b}$ & 7,85 & $1,43 b$ \\
\hline $30 \mathrm{~F} 80$ & $1,49 b$ & 1,20 & $1,64 \mathrm{a}$ & 2,81 & $1,44 b$ & $-0,87$ & $1,63 \mathrm{a}$ & 0,11 & $1,37 \mathrm{c}$ & $-5,62$ & $1,49 b$ & 2,36 & $1,43 b$ \\
\hline EH & $1,18 \mathrm{~d}$ & & $1,45 b$ & & $1,24 d$ & & $1,54 \mathrm{~b}$ & & $1,31 \mathrm{c}$ & & $1,34 \mathrm{c}$ & & \\
\hline \multicolumn{14}{|c|}{ Controls } \\
\hline \multicolumn{3}{|c|}{ Cargo } & \multicolumn{4}{|c|}{ Status } & \multicolumn{3}{|c|}{ Celeron } & \multicolumn{4}{|c|}{ Penta } \\
\hline \multicolumn{3}{|c|}{$1,47 \mathrm{~b}$} & \multicolumn{3}{|c|}{$1,53 \mathrm{~b}$} & & \multicolumn{3}{|c|}{$1,27 \mathrm{c}$} & \multicolumn{4}{|c|}{$1,37 \mathrm{c}$} \\
\hline
\end{tabular}

Means followed by the same letter belong to the same group according to the Scott Knott method at a $5 \%$ probability.

Table 9. Estimates of the specific combining ability $\left(\hat{\mathbf{s}}_{\mathrm{ij}}\right)$ and ear height means $(\mathrm{m})$ in year $2(2012 / 2013)$ for 22 parents, 96 hybrid combinations and 4 maize controls in Sabáudia/PR, Brazil.

\begin{tabular}{|c|c|c|c|c|c|c|c|c|c|c|c|c|c|}
\hline & \multicolumn{2}{|c|}{ AG8088 } & \multicolumn{2}{|c|}{ AG7088 } & \multicolumn{2}{|c|}{ AG9045 } & \multicolumn{2}{|c|}{ AG8021 } & \multicolumn{2}{|c|}{ AG9040 } & \multicolumn{2}{|c|}{ AG7010 } & \multirow{2}{*}{$\mathrm{EH}$} \\
\hline & $\mathrm{EH}$ & $\hat{\mathbf{s}}_{\mathrm{ij}}$ & $\mathrm{EH}$ & $\hat{\mathbf{s}}_{\mathrm{ij}}$ & $\mathrm{EH}$ & $\hat{\mathbf{s}}_{\mathrm{ij}}$ & $\mathrm{EH}$ & $\hat{\mathbf{s}}_{\mathrm{ij}}$ & $\mathrm{EH}$ & $\hat{\mathbf{s}}_{\mathrm{ij}}$ & $\mathrm{EH}$ & $\hat{\mathbf{s}}_{\mathrm{ij}}$ & \\
\hline $30 \mathrm{~F} 35$ & $0,94 d$ & $-17,5$ & $1,13 \mathrm{c}$ & $-1,68$ & $1,04 \mathrm{c}$ & $-5,15$ & $1,16 b$ & 3,25 & $1,09 \mathrm{c}$ & 6,66 & $1,15 b$ & 14,51 & $1,10 \mathrm{~d}$ \\
\hline 3021 & $1,26 b$ & 14,51 & $1,22 \mathrm{~b}$ & $-1,46$ & $1,27 b$ & 8,59 & $1,15 b$ & $-7,18$ & $1,20 \mathrm{~b}$ & 9,06 & $0,96 \mathrm{~d}$ & $-14,1$ & $1,18 \mathrm{~b}$ \\
\hline $30 \mathrm{~K} 64$ & $1,19 b$ & $-10,5$ & $1,31 \mathrm{a}$ & $-1,19$ & $1,31 \mathrm{a}$ & 4,49 & $1,32 \mathrm{a}$ & 1,24 & $1,15 b$ & $-4,51$ & $1,29 a$ & 10,83 & $1,14 \mathrm{c}$ \\
\hline $30 \mathrm{~F} 53$ & $1,30 \mathrm{a}$ & 8,47 & $1,28 \mathrm{a}$ & 4,36 & $1,11 \mathrm{c}$ & $-7,24$ & $1,26 b$ & 3,64 & $1,07 \mathrm{c}$ & $-4,68$ & $1,05 \mathrm{c}$ & $-4,56$ & $1,18 \mathrm{~b}$ \\
\hline P3646 & $1,28 \mathrm{a}$ & 0,88 & $1,25 b$ & $-4,46$ & $1,23 b$ & $-1,68$ & $1,31 \mathrm{a}$ & 2,14 & $1,21 b$ & 2,14 & $1,16 b$ & $-0,34$ & $1,22 b$ \\
\hline P1630 & $1,21 \mathrm{~b}$ & 3,17 & $1,15 b$ & $-5,93$ & $1,32 \mathrm{a}$ & 16,62 & $1,07 \mathrm{c}$ & $-11,9$ & $1,17 \mathrm{~b}$ & 9,17 & $0,96 \mathrm{~d}$ & $-11,1$ & $1,16 \mathrm{~b}$ \\
\hline 30B39 & $1,32 \mathrm{a}$ & $-8,63$ & $1,45 \mathrm{a}$ & 1,85 & $1,34 \mathrm{a}$ & $-3,69$ & $1,43 a$ & 1,38 & $1,28 \mathrm{a}$ & $-3,12$ & $1,42 \mathrm{a}$ & 12,22 & $1,22 b$ \\
\hline $32 \mathrm{R} 48$ & $1,40 \mathrm{a}$ & 19,51 & $1,25 b$ & 2,07 & $1,04 \mathrm{c}$ & $-13,2$ & $1,28 \mathrm{a}$ & 5,93 & $0,93 \mathrm{~d}$ & $-17,81$ & $1,13 \mathrm{c}$ & 3,55 & $1,15 b$ \\
\hline $30 \mathrm{R} 22$ & $1,07 \mathrm{c}$ & 3,55 & $1,25 b$ & 4,84 & $1,14 b$ & $-0,29$ & $1,20 \mathrm{~b}$ & 1,03 & $1,08 \mathrm{c}$ & 0,69 & $1,11 \mathrm{c}$ & 4,79 & $0,90 \mathrm{~d}$ \\
\hline P3340 & $1,08 \mathrm{c}$ & $-2,01$ & $1,12 \mathrm{c}$ & $-1,11$ & $1,20 b$ & 12,69 & $1,09 \mathrm{c}$ & $-2,25$ & $1,00 \mathrm{c}$ & $-0,17$ & $0,92 d$ & $-7,13$ & $0,83 d$ \\
\hline P30K 73 & $1,10 \mathrm{c}$ & $-9,98$ & $1,21 \mathrm{~b}$ & $-1,40$ & $1,24 b$ & 7,03 & $1,23 b$ & 2,11 & $1,14 \mathrm{c}$ & 3,85 & $1,07 \mathrm{c}$ & $-1,62$ & $1,14 \mathrm{c}$ \\
\hline P4285 & $1,26 b$ & 9,37 & $1,20 \mathrm{~b}$ & 0,68 & $1,00 \mathrm{~d}$ & $-14,2$ & $1,26 b$ & 7,88 & $1,02 \mathrm{c}$ & $-5,03$ & $1,07 \mathrm{c}$ & 1,33 & $1,05 \mathrm{c}$ \\
\hline P30F36 & $1,01 \mathrm{c}$ & $-18,7$ & $1,19 b$ & $-2,37$ & $1,13 \mathrm{c}$ & $-2,93$ & $1,16 \mathrm{~b}$ & $-4,10$ & $1,30 \mathrm{a}$ & 20,13 & $1,16 b$ & 7,98 & $1,26 \mathrm{~b}$ \\
\hline $30 \mathrm{R} 50$ & $1,42 \mathrm{a}$ & 26,25 & $1,22 b$ & 3,81 & $1,22 b$ & 9,70 & $1,05 \mathrm{c}$ & $-11,9$ & $0,96 \mathrm{~d}$ & $-10,24$ & $0,87 d$ & $-17,6$ & $1,38 \mathrm{a}$ \\
\hline 30B30 & $1,22 b$ & $-11,0$ & $1,30 \mathrm{a}$ & $-5,98$ & $1,19 b$ & $-11,1$ & $1,38 \mathrm{a}$ & 3,95 & $1,32 \mathrm{a}$ & 8,60 & $1,38 \mathrm{a}$ & 15,62 & $1,18 \mathrm{~b}$ \\
\hline $30 \mathrm{~F} 80$ & $1,40 \mathrm{a}$ & 17,08 & $1,33 \mathrm{a}$ & 7,98 & $1,20 \mathrm{~b}$ & 0,53 & $1,28 \mathrm{a}$ & 4,75 & $0,97 d$ & $-16,07$ & $0,97 \mathrm{~d}$ & $-14,2$ & $1,35 \mathrm{a}$ \\
\hline EH & $1,32 \mathrm{a}$ & & $1,45 \mathrm{a}$ & & $1,29 \mathrm{a}$ & & $1,26 \mathrm{~b}$ & & $1,08 \mathrm{c}$ & & $0,82 \mathrm{~d}$ & & \\
\hline \multicolumn{14}{|c|}{ Controls } \\
\hline \multicolumn{3}{|c|}{ Cargo } & \multicolumn{4}{|c|}{ Status } & \multicolumn{3}{|c|}{ Celeron } & \multicolumn{4}{|c|}{ Penta } \\
\hline \multicolumn{3}{|c|}{$1,17 \mathrm{~b}$} & \multicolumn{4}{|c|}{$1,01 \mathrm{c}$} & \multicolumn{3}{|c|}{$1,21 \mathrm{~b}$} & \multicolumn{4}{|c|}{$1,04 \mathrm{c}$} \\
\hline
\end{tabular}

Means followed by the same letter belong to the same group according to the Scott Knott method at a 5\% probability. 
Table 10. Estimates of $\hat{\mu}+\hat{a}$ and relative percentage of inbreeding depression (\% ID) for productivity (Yield.; $\mathrm{t}$ $\left.\mathrm{ha}^{-1}\right)$, plant height $(\mathrm{PH} ; \mathrm{cm})$ and ear height $(\mathrm{EH} ; \mathrm{cm})$, in the average environments, year $1(2011 / 2012)$ and year 2 (2012/2013), respectively.

\begin{tabular}{|c|c|c|c|c|c|c|c|c|c|c|}
\hline \multirow{3}{*}{ Parents } & \multirow{2}{*}{\multicolumn{2}{|c|}{ Yield }} & \multicolumn{4}{|c|}{ PH } & \multicolumn{4}{|c|}{ EH } \\
\hline & & & \multicolumn{2}{|c|}{$2011 / 2012$} & \multicolumn{2}{|c|}{$2012 / 2013$} & \multicolumn{2}{|c|}{$2011 / 2012$} & \multicolumn{2}{|c|}{$2012 / 2013$} \\
\hline & $\hat{u}+\hat{a}$ & $\%$ ID & $\hat{u}+\hat{a}$ & $\%$ ID & $\hat{u}+\hat{a}$ & $\%$ ID & $\hat{u}+\hat{a}$ & $\%$ ID & $\hat{u}+\hat{a}$ & $\%$ ID \\
\hline $30 \mathrm{~F} 35$ & 1,34 & 42,64 & 186,94 & 14,62 & 224,87 & $-6,12$ & 119,46 & 12,80 & 114,96 & $-1,83$ \\
\hline 3021 & 6,91 & $-25,36$ & 215,80 & 3,83 & 201,87 & 5,06 & 133,26 & 2,83 & 127,61 & $-3,92$ \\
\hline $30 \mathrm{~K} 64$ & 0,02 & 49,91 & 180,82 & 15,89 & 201,82 & 4,07 & 106,53 & 16,32 & 91,654 & 9,83 \\
\hline $30 \mathrm{~F} 53$ & 0,97 & 43,46 & 155,18 & 18,51 & 197,67 & 7,92 & 93,51 & 17,95 & 115,07 & 1,63 \\
\hline P3646 & 2,08 & 39,18 & 185,72 & 11,62 & 207,32 & 4,02 & 92,454 & 18,27 & 87,79 & 14,23 \\
\hline P1630 & 4,61 & 17,96 & 207,70 & 7,64 & 221,38 & $-0,68$ & 143,17 & $-9,03$ & 105,127 & 4,99 \\
\hline 30B39 & 3,13 & 31,97 & 127,02 & 27,00 & 203,22 & 5,54 & 51,78 & 34,90 & 90,92 & 12,95 \\
\hline $32 \mathrm{R} 48$ & 1,05 & 41,00 & 175,71 & 12,00 & 210,21 & 2,40 & 92,406 & 13,62 & 112,82 & 1,19 \\
\hline $32 \mathrm{R} 22 \mathrm{H}$ & 0,69 & 44,50 & 171,01 & 16,09 & 225,51 & $-1,26$ & 85,67 & 17,65 & 162,47 & $-39,99$ \\
\hline P3340 & 2,38 & 36,81 & 159,48 & 18,37 & 274,54 & $-29,00$ & 89,051 & 19,84 & 150,47 & $-40,62$ \\
\hline P30K73 & 2,98 & 31,87 & 236,62 & 4,08 & 267,74 & $-10,95$ & 139,00 & 4,49 & 139,905 & $-11,02$ \\
\hline P4285 & 3,76 & 28,80 & 221,12 & 8,37 & 255,99 & $-14,85$ & 134,13 & 7,74 & 127,83 & $-10,55$ \\
\hline P30F36 & 2,88 & 27,94 & 201,87 & 8,81 & 217,68 & 3,35 & 116,04 & 10,32 & 106,42 & 7,84 \\
\hline 30R50 & 1,62 & 37,30 & 195,32 & 5,44 & 176,35 & 13,52 & 116,08 & 8,49 & 52,68 & 30,95 \\
\hline 30B30 & 1,99 & 36,61 & 224,32 & 4,01 & 174,23 & 12,76 & 139,07 & 1,50 & 75,55 & 18,03 \\
\hline $30 \mathrm{~F} 80$ & 1,81 & 33,74 & 178,25 & 10,50 & 168,42 & 15,97 & 115,23 & 9,88 & 70,64 & 23,94 \\
\hline AG8088 & 1,09 & 43,60 & 178,37 & 11,89 & 216,81 & 4,69 & 98,748 & 8,16 & 77,94 & 20,53 \\
\hline AG7088 & 3,51 & 28,41 & 177,85 & 12,52 & 163,37 & 17,40 & 111,96 & 11,46 & 33,19 & 38,62 \\
\hline AG9045 & 2,46 & 33,31 & 164,93 & 13,27 & 185,63 & 11,50 & 93,077 & 12,65 & 76,49 & 20,42 \\
\hline AG8021 & 6,00 & 7,47 & 201,71 & 11,45 & 184,29 & 11,21 & 113,70 & 13,16 & 94,23 & 12,71 \\
\hline AG9040 & $-0,42$ & 53,08 & 135,58 & 20,16 & 217,92 & $-0,10$ & 89,46 & 15,96 & 128,46 & $-8,96$ \\
\hline AG7010 & 4,54 & 7,43 & 185,89 & 10,67 & 256,95 & $-23,22$ & 83,68 & 18,99 & 149,79 & $-40,75$ \\
\hline
\end{tabular}

Pacheco (1997) reported a negative and almost perfect correlation $(\mathrm{r}=-0.98)$ between the estimated mean of the inbred lines and the percentage of inbreeding of 28 maize populations. The reduction in average yield due to inbreeding was associated with a reduction in the predicted mean for inbred lines extracted from the population. Because the majority of parents used in this experiment are simple hybrids, the high percentages for the reduction of yield with self-pollinization indicate large amounts of genetic complementation between the inbred lines involved in their formation. This complementation results in elevated levels of heterosis from crossings between inbred lines of contrasting heterotic groups. In contrast, the hybrids that showed lower magnitudes of inbreeding depression were likely formed from crossings between inbred lines with higher frequencies of favorable alleles with additive effects that add up in each hybrid to constitute the important phenotypes in the evaluated environments.

Many authors have highlighted the potential of populations of commercial maize hybrids in the production of the so-called intermediate hybrids through the crossing of $\mathrm{F}_{2}$ generations from the commercial hybrids, with the objective of reducing costs and accelerating the process of forming new, superior hybrids. Amorim and Souza (2005) studied $\mathrm{S}_{1}$ populations derived from simple commercial hybrids to verify the viability of hybrid production 
from these populations. The authors observed that specific hybrid combinations overcame the means of the witnesses and the means of the populations in question, demonstrating the potential of the genotypes in the production of intermediate hybrids. Similar results were obtained by Carvalho et al. (2004), Garbuglio and Araújo (2006), Santos (2009), Bernini and Paterniani (2012) and Bernini et al. (2013).

\section{Conclusions}

The parents selected for grain yield (30B30, 30K64 and 30B39), plant height (P1630 and 30F53) and ear height (AG9040 and AG7010) can be used in the formation of synthetics for the extraction of inbred inbred lines that reunite traits of interest.

The combinations 30B39 x AG9045, 30B39 x AG8088, 30B30 x AG7010, 30K64 x AG8088 and 30K64 x AG7010 were the most promising with respect to productivity.

The populations derived from the hybrids AG8021, P1630, 3021, AG7010, P4285, AG7088 and 30B39 offer greater opportunities for success in the synthesis of inbred inbred lines with superior grain yields.

\section{Acknowledgments}

The authors acknowledge the National Council for Scientific and Technological Development (Conselho Nacional de Desenvolvimento Científico e Tecnológico - CNPq) for the financial support provided and the company Sementes Balu for their partnership, support and confidence in this study.

\section{References}

AMORIM, E. P.; SOUZA, J. C. de. Híbridos de milho inter e intrapopulacionais obtidos a partir de populações $\mathrm{S}_{0}$ de híbridos simples comerciais. Bragantia, Campinas, v. 64, n. 4 , p. 561-567, 2005.
BERNINI, C. S.; PATERNIANI, M. E. A. G. Z. Estimativas de parâmetros de heterose em híbridos de populações $\mathrm{F}_{2}$ de milho. Pesquisa Agropecuária Tropical, Goiânia, v. 42, n. 1, p. 56-62, 2012.

BERNINI, C. S.; PATERNIANI, M. E. A. G. Z.; DUARTE, A. P.; GALlO, P. B.; GUIMARÃES, P. S.; ROVARIS, S. R. S. Depressão endogâmica e heterose de híbridos de populações $\mathrm{F}_{2}$ de milho no estado de São Paulo. Bragantia, Campinas, v. 72, n. 3, p. 217-223, 2013.

CARVAlHO, A. D.; SOUZA, J. C.; RAMALHO, M. A. P. Capacidade de combinação de progênies parcialmente endogâmicas obtidas de híbridos comerciais de milho. Revista Brasileira de Milho e Sorgo, Sete Lagoas, v. 3, n. 3, p. 429-437, 2004.

CRUZ, C. D. Genes - a software package for analysis in experimental statistics and quantitative genetics. Acta Scientiarum, Maringá, v. 35, n. 3, p. 271-276, 2013.

CRUZ, C. D.; REGAZZI, A. J.; CARNEIRO, P. C. S. Modelos biométricos aplicados ao melhoramento genético. 3. ed. Viçosa, MG: UFV, 2007. 514 p.

CRUZ, C. D.; VENCOVSKY, R. Comparação de alguns métodos de análise dialélica. Revista Brasileira de Genética. Ribeirão Preto, v. 12, n. 2, p. 425-438, 1989.

FALCONER, D. S. Introdução à genética quantitativa. Viçosa, MG: UFV, Imprensa Universitária, 1987. 279 p.

FRITSCHE-NETO, R.; VIEIRA, R. A.; SCAPIM, C. A.; MIRANDA, G. V.; REZENDE, L. M. Updating the ranking of the coefficientes of variantion from maize experiments. Acta Scientiarum, Maringá, v. 34, n. 1, p. 99-101, 2012.

GAlVÃO, J. C. C.; MIRANDA, G. V. Tecnologias de produção do milho. Viçosa, MG: UFV, 2008. 366 p.

GARBUGLIO, D. D.; ARAÚJO, P. M. de. Avaliação de híbridos intervarietais de milho por meio do cruzamento dialélico parcial, considerando quatro ambientes. Semina: Ciências Agrárias, Londrina, v. 27, n. 3, p. 379-392, 2006.

GARDNER, C. O. Teoria de genética estadística aplicable a las medias de variedades, sus cruces y poblaciones afines. Fitotecnica Latinoamericana, Caracas, v. 2, n. 1-2, p. 11-22, 1965.

GARDNER, C. O.; EBERHART, S. A. Analysis and interpretation of the variety cross diallel and related populations. Biometrics, Raleigh, v. 22, n. 3, p. 439-452, 1966.

GERALDI, I. O.; MIRANDA FILHO, J. B. Adapted models for the analysis of combining ability of varieties in partial diallel corsses. Revista Brasileira de Genética, Ribeirão Preto, v. 11, n. 2, p. 419-430, 1988. 
GOMES, F. P. Curso de estatística experimental. 7. ed. Piracicaba: ESALQ/USP, 1977. 451 p.

GORGULHO, E. P.; MIRANDA FILHO, J. B. Estudo da capacidade combinatória de variedades de milho no esquema de cruzamento dialélico parcial. Bragantia, Campinas, v. 60, n. 1, p. 1-8, 2001.

GRIFFING, B. Concept of general and specific combining ability in relation to diallel crossing system. Australian Journal of Biological Sciences, Melbourne, v. 9, n. 4, p. 463-493, 1956.

HALLAUER, A. R.; CARENA, M. J.; MIRANDA FILHO, J. B. Quantitative genetics in maize breeding. $3^{\text {th }}$ ed. Nova Iorque: Springer, 2010. 664 p.

HARTLEY, H. O. The use of range in analysis of variance. Biometrika, Oxford, v. 37, n. 3-4, p. 271-280, 1950.

HAYMAN, B. I. The theory and analysis of diallel crosses. Genetics, Bethesda, v. 39, n. 6, p. 789-809, 1954.

LAMKEY, K. R.; PETERSON, P. A.; HALLAUER, A. R. Frequency of the transposable element UQ in Iowa Stiff Stalk Synthetic Maize Populations. Genetics Research, Cambridge, v. 57, n. 1, p. 1-9, 1991.

LIMA, M. W. P.; SOUZA, E. A.; RAMALHO, M. A. P. Procedimentos para escolha de populações de milho promissoras para extração de linhagens. Bragantia, Campinas, v. 59, n. 2, p. 153-158, 2000.

LOCATELLI, A. B.; FEDERIZZI, L. C.; NASPOLINI FILHO, V. Capacidade combinatória de nove linhagens endogâmicas de milho (Zea mays L.) em dois ambientes. Ciência Rural, Santa Maria, v. 32, n. 3, p. 365-370, 2002.

MIKEL, M. A. Genetic composition of contemporary U. S. commercial dent corn germplasm. Crop Science, Madison, v. 51, n. 2, p. 592-599, 2011.

MIRANDA FILHO, J. B.; GORGUlhO, E. P. Cruzamentos com testadores e dialelos. In: NASS, L. L.; VALOIS, A. C. C.; MELO, I. S. de; VALADARESINGLIS, M. C. Recursos genéticos e melhoramento: plantas. Rondonópolis: Fundação MT, 2001. p. 649-670.

OLIBONI, R.; FARIA, M. V.; NEUMANN, M.; RESENDE, J. T. V.; BATTISTELLI, G. M.; TEGONI, R. G.; OLIBONI, D. F. Análise dialélica na avaliação do potencial de híbridos de milho para a geração de populações-base para obtenção de linhagens. Semina: Ciências Agrárias, Londrina, v. 34, n. 1, p. 7-18, 2013.

PACHECO, C. A. P. Associação das metodologias de análise dialélica de Griffing e de análise de adaptabilidade e estabilidade de Eberhart e Russel. 1997. Tese (Doutorado em Genética e Melhoramento) Universidade Federal de Viçosa, Viçosa, MG.
PFANN, A. Z.; FARIA, M. V.; ANDRADE, A. A.; NASCIMENTO, I. R.; FARIA, C. M. D. R.; BRINGHENTTI, R. M. Capacidade combinatória entre híbridos simples de milho em dialelo circulante. Ciência Rural, Santa Maria, v. 39, n. 3, p. 635-641, 2009.

PINTO, R. M. C.; GARCIA, A. A. F.; SOUZA JÚNIOR, C. L. Alocação de linhagens de milho derivadas das populações BR-105 e BR-106 em grupos heteróticos. Scientia Agrícola, Piracicaba, v. 58, n. 3, p. 541-548, 2001.

RAPOSO, F. V.; RAMALHO, M. A. P. Componentes de variância genética de populações derivadas de híbridos simples de milho. Revista Brasileira de Milho e Sorgo, Sete Lagoas, v. 3, n. 3, p. 402-413, 2004.

REGAZZI, A. J.; SILVA, H. D.; VIANA, J. M. S.; CRUZ, C. D. Análise de experimentos em látice quadrado com ênfase em componentes de variância. II. Análise conjunta. Pesquisa Agropecuária Brasileira, Brasília, v. 34, n. 11, p. 1987-1997, 1999.

SANTOS, F. M. da C. Capacidade de combinação de híbridos comerciais de milho visando á obtenção de híbridos de $F_{2}$. 2009. Dissertação (Mestrado em Genética, Melhoramento Vegetal e Biotecnologia) Instituto Agronômico de Campinas, Campinas.

SANTOS, J. B.; VENCOVSKY, R.; RAMALHO, M. A. P. Controle genético da produção de grãos e de seus componentes primários em feijoeiro. Pesquisa Agropecuária Brasileira, Brasília, v, 20, n. 10, p. 1203-1211, 1985.

SAWAZAKI, E.; PATERNIANI, M. E. A. G. Z.; CASTRO, J. L.; GALlO, P. B.; GALVÃO, J. C. C.; SAES, L. A. Potencial de linhagens de populações locais de milho pipoca para síntese de híbridos. Bragantia, Campinas, v. 59, n. 2, p. 143-151, 2000.

SCAPIM, C. A.; CARVALHO, C. G. P.; CRUZ, C. D. Uma proposta de classificação dos coeficientes de variação para a cultura do milho. Pesquisa Agropecuária Brasileira, Brasília, v. 30, n. 5, p. 683-686. 1995.

SCAPIM, C. A.; PACHECO, C. A. P.; TONET, A.; BRACCINI, A. L.; PINTO, R. J. B. Análise dialélica e heterose de populações de milho-pipoca. Bragantia, Campinas, v. 61, n. 3, p. 219-230, 2002.

SILVA, H. D.; REGAZZI, A. J.; CRUZ, C. D.; VIANA, J. M. S. Análise de experimentos em látice quadrado com ênfase em componentes de variância. I. Análises individuais. Pesquisa Agropecuária Brasileira, Brasília, v. 34, n. 10, p. 1811-1822, 1999.

SPRAGUE, G. F.; TATUM, L. A. General vs. specific combining ability in single crosses of corn. Journal of American Society of Agronomy, Madison, v. 34, n. 10, p. 923-932, 1942. 
TROYER, A. F. Breeding widely adapted, popular maize hybrids. Euphytica, Wageningen, v. 92, n. 1-2, p. 163174, 1996.

VENCOVSKY, R.; BARRIGA, P. Genética biométrica no fitomelhoramento. Ribeirão Preto: Sociedade Brasileira de Genética, 1992. 496 p.
VENCOVSKY, R.; CRUZ, C. D. Comparação de métodos de correção do rendimento de parcelas com estandes variados. I. Dados simulados. Pesquisa Agropecuária Brasileira, Brasília, v. 26, n. 5, p. 647657, 1991. 
